\title{
Numerical analysis of the thermal comfort in a church building
}

\author{
Florin Emilian Țurcanu ${ }^{1, *}$, Marina Verdeș $^{1}$, Vasilică Ciocan $^{1}$, Andrei Burlacu ${ }^{1}$, Răzvan Silviu Luciu ${ }^{1}$, Marius \\ Costel Bălan ${ }^{1}$, and Gavril Șosoi ${ }^{1,2}$ \\ ${ }^{1}$ Gheorghe Asachi” Technical University of Iași, Faculty of Civil Engineering and Building Services, 700050 Iași, Romania \\ 2 Aix-Marseille Université, IUSTI UMR 7343, 13453 Marseille Cedex 13, France
}

\begin{abstract}
Based on the monitoring campaigns, we have evaluated the indoor microclimate in a church. Most church buildings are characterised by low thermal comfort due primarily to their architecture, heating huge volume of air. The CFD tools was used for thermal comfort evaluation in case of the existing heating system during the winter season. The simulation model was validated with experimental data and it was used for thermal and air velocity profiles in the occupancy zone of churchgoers. The aim of the paper is the study the feasibility of maintaining the heritage values of the churches while achieving the significant improvement of the thermal comfort.
\end{abstract}

\section{Introduction}

The energy cost for heating large space, especially churches is quite high. Problems increases in success spaces where only for a small zone the thermal comfort is needed. A local heating, should be a nice solution for minimizing the heat cost but still having human thermal comfort. [1]

To address this issue, in this paper the problems of church heating is presented, in which the performance of a static heating in the church of St. Apostol's Peter and Paul in Jassy, also called Cetăția church monastery is investigated.

Aside from the high energy cost that the heating system generate, there are other problems in the church when is heated during the winter. In order to heat the interior of the church for the daily mass is used a hot water static heaters $\left(\mathrm{T}_{\text {supply }}=90^{\circ} \mathrm{C}, \mathrm{T}_{\text {return }}=70^{\circ} \mathrm{C}\right)$, thus introducing abrupt variation in temperature and more importantly, in the relative humidity of the indoor air. These variations have been known to cause damage to the church buildings and its cultural heritage patrimony. [1]

In order to find a solution, a heating system that uses underfloor heating is designed and tested. First the CFD model of static heaters is presented as well as the verification of the CFD results with the help of the indoor measurements. After that, the influence of the existing and proposed heating system on the indoor climate is shown. [2][3]

Churches preserve many kinds of valuable artworks, each of them with a specific vulnerability, paintings on walls and wooden panels are subjected to cracking, swelling, blistering and soiling. [3]

\section{Church of St. Apostol's Peter and Paul (Cetățuia Monastery) from Jassy - case study}

The church was founded by voivode Gheorghe Duca in the XVII century, between 1669-1672 Fig. 1.

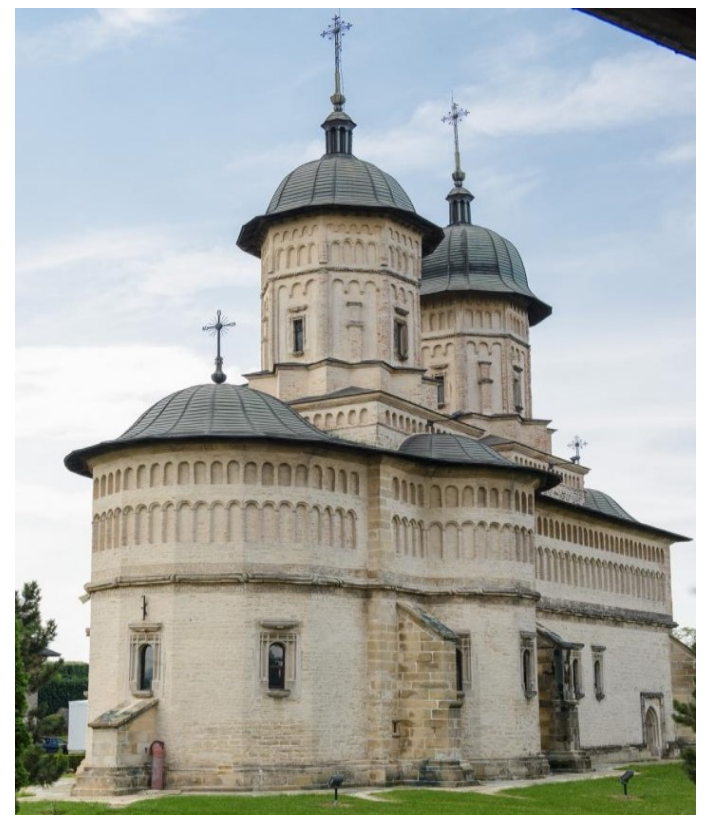

Fig. 1. Exterior view the Cetăţuia Monastery.

The interior of the church is divided into the main part of an orthodox church as follows: a closed porch, narthex, nave and sanctuary (Fig. 2).

\footnotetext{
* Corresponding author: turcanufemilian $@$ gmail.com
} 


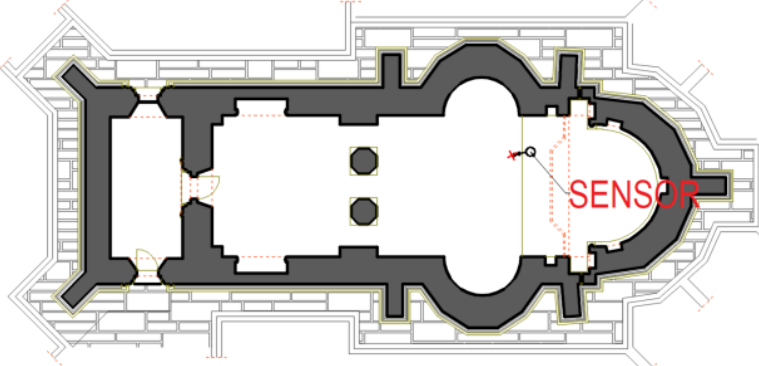

Fig. 2. Plan view at \pm 0.00 m of Cetățuia Monastery.

Also the church surprise the eye through the windows made in gothic style, having $0.5 \mathrm{~m}$ in width and 1.5 in height with the wall dimension of $1.35 \mathrm{~m}$, made from brick and limestones. In plane, the church has the width of $9,80 \mathrm{~m}$, the length of $30 \mathrm{~m}$, the height to the ceiling of $10,60 \mathrm{~m}$ and the total height in the towers of $21,70 \mathrm{~m}$. The fact the church is built in triconch plan together with the two orthogonal towers gives a unique image of the church (Fig. 3).

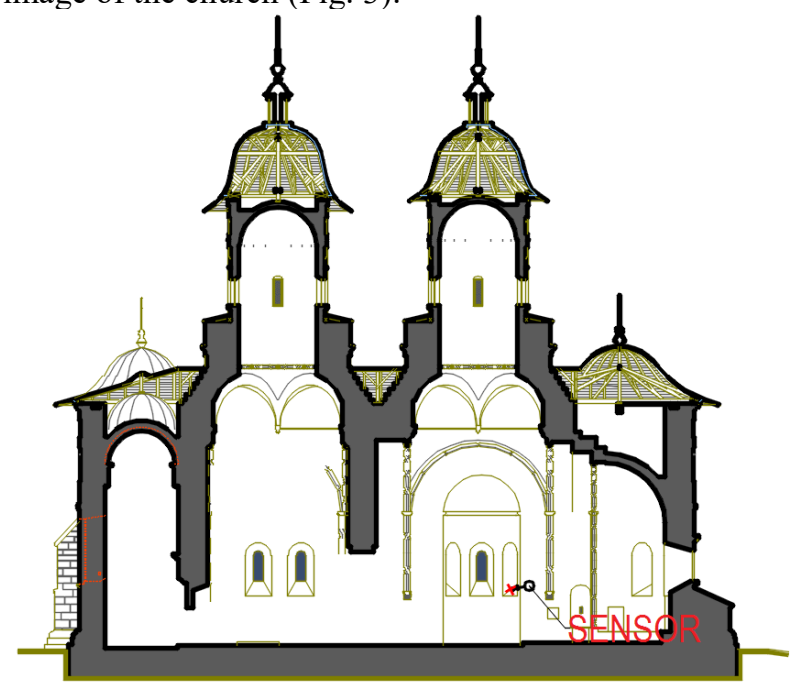

Fig. 3. Plan view at \pm 0.00 m of Cetățuia Monastery.

The church houses the old furniture of the royal and clergy pew, richly decorated with leaves, golden flowers and angels with large hands. The pictorial ensemble of the church is of great artistic value Fig 4.

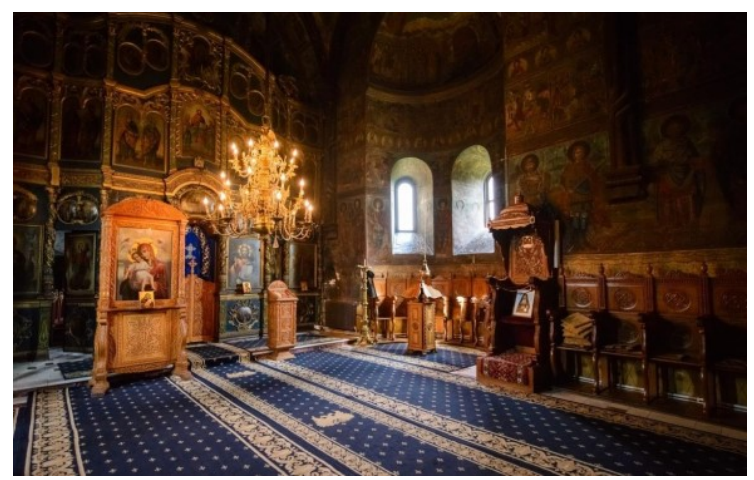

Fig. 4. Old iconostasis and pew in Cetăţuia Monastery.

The church was painted in 1673 in a fresco by the aromanian painters from Greece helped by romanian painters that worked at Church of Three Hierarchs, also from Jassy. The original painting has been preserved only partially, changes been made in XVII and XIX century. In the vest wall has been preserved the paint of Gheorghe Duca, the founder family (Fig. 5).

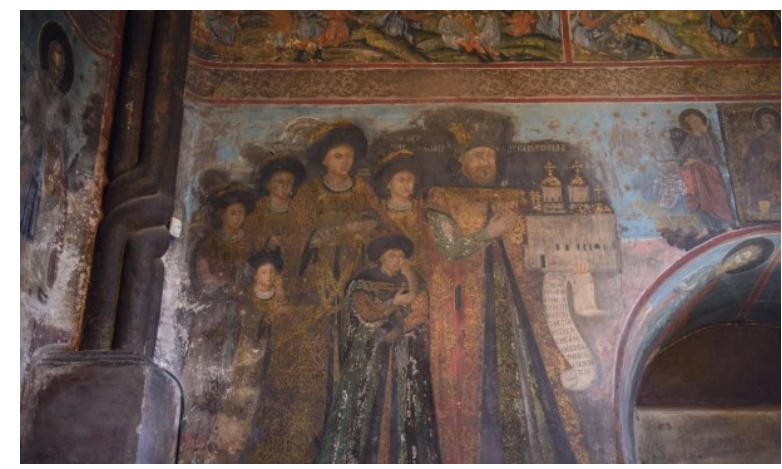

Fig. 5. Gheorghe Duca founder family in Cetățuia Monastery.

\subsection{Hot water static heating system}

Static heaters operate as natural convectors, air enters at the bottom of the static heaters and rises due to buoyancy at the top (Fig.6).

In traditional hot water heating system present in churches, static heaters are installed through the church, at some distance from or very close to pews. Static heaters have a visual impact and may blacken nearby surfaces or damage woodworks. Is better to avoid placing them closed to or below valuable pews (Fig.5).

Hot water heating systems generate gentle air motions that are sufficient to blackening walls, especially above the support brackets. Above the brackets the uprising warm air becomes turbulent increasing the blackening rate (Fig. 6). The main deposit mechanism is the inertial impaction, which acts in synergism with thermophoresis and Brownian motions. So that the static heaters should be positioned below frescos to avoid damage for T-rH cycles and blackening. (Fig. 7) [4]

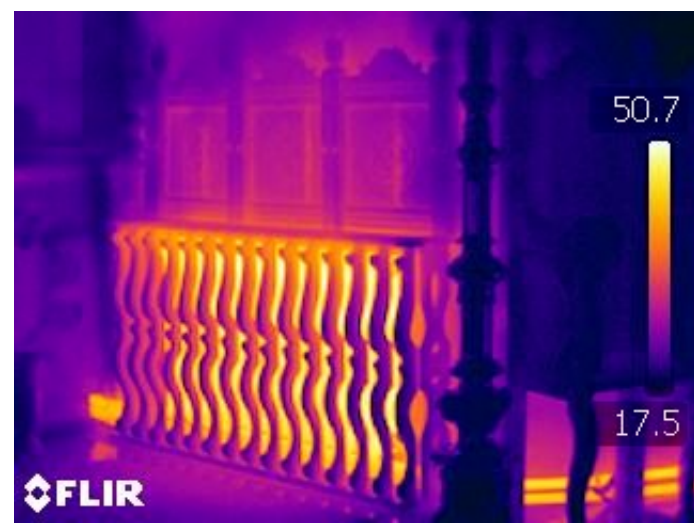

Fig. 6. Static heaters placed in pew from Cetățuia Monastery view with thermal imaging camera.

To be efficient the system needs to be turn on in plenty of time and the level or comfort is proportional with the number of static heaters, with the temperature of thermos-convective fluid, also with how long the system is kept in operation before the church is used. 


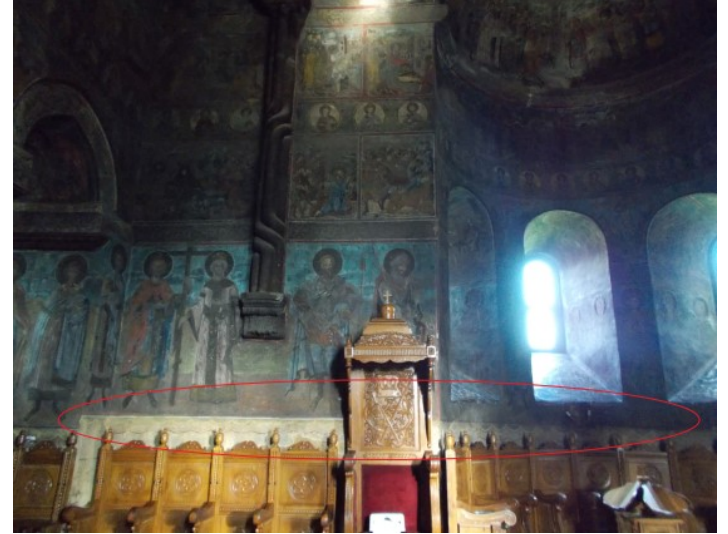

Fig. 7. Blackening due to static heaters placed in pew from Cetățuia Monastery.

\subsection{Underfloor heating system}

To improve to thermal comfort condition and to reduce the damage to the artwork in the church is proposed to use a complementary heating system. By choosing an underfloor heating system the thermo-convective fluid temperature is reduced in the static heaters placed in the pews and so the air movement that cause blacking and damage to the frescos on the wall is gradually minimized. (Fig. 8). [4]

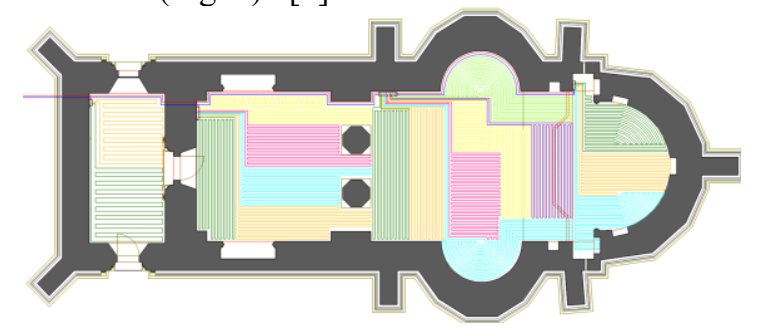

Fig. 8. The proposed underfloor heating system to be placed in Cetățuia Monastery.

As is known, underfloor heating system uses pipes embedded in the flooring. The pipes carry hot water ( $\mathrm{T}_{\text {supply }}=40^{\circ} \mathrm{C}, \mathrm{T}_{\text {return }}=20^{\circ} \mathrm{C}$ ) that can be provided by any source. Instead of hot water pipes, electrically heated cables or mats can be used. The floor is gradually heated and provides a comfortable feeling of radiating warmth from below. About one is required to reach equilibrium. A makeshift, less invasive solution is to install a footboard with embedded water pipes or electrical heating cables on the floor, as a basement for pews. This solutions leaves the floor untouched, but less efficient. [5]

\section{Campaign of measurements in church of Cetățuia Monastery}

The existing heating system is composed from static heaters (Fig.5) placed in the pews (Fig. 3). The main purpose of this research being is to evaluate the microclimate created in the church and also the heritage conservation condition. There has been done an analysis in CFD environment to evaluate the physical arrangement of temperature inside the hole volume and the air movements caused by static heating system. It had been created a campaign of measurements for the main parameters, temperature $\left({ }^{\circ} \mathrm{C}\right)$ and air relative humidity (\%), the aim been also to validate the plan of measurements with the simulation of indoor climate done in Autodesk CFD 2019 software. [5] [6]

For evaluating the microclimate in the church of Cetățuia Monastery there have been utilized equipment as thermal imaging camera from Flir, USB Data Logger DS 100 for temperature $\left(\mathrm{T}-{ }^{0} \mathrm{C}\right)$ and relative humidity $(\mathrm{rH}-\%)$. The sensor have been placed at the top of Mother of God icon, in a determinant and important position seen in figure 9, figure 4 and as is drawn in architectural plan from figure 2,3 .

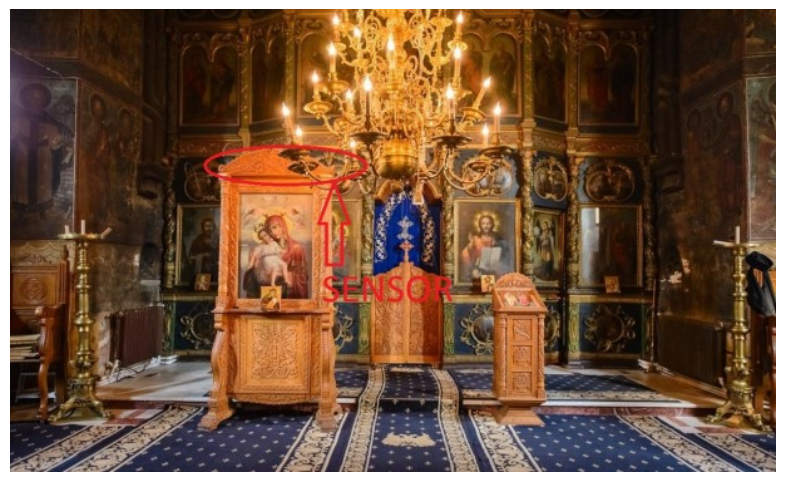

Fig. 9. Senzor placement in Cetățuia Monastery.

The campaign measurements take place during the winter season between 03.20.2017-06.03.2017. During this period the outside temperature has a minim of $\mathrm{T}=$ $16,2^{\circ} \mathrm{C}$ and maximum of $\mathrm{T}=+9,9^{\circ} \mathrm{C}$.

The graphical variation of the comfort parameters during this period are show in Figure 10.

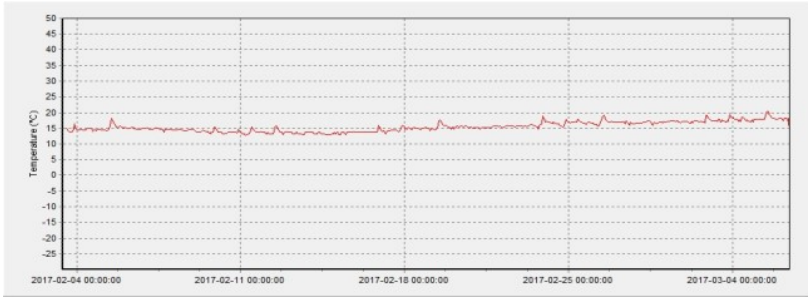

a)

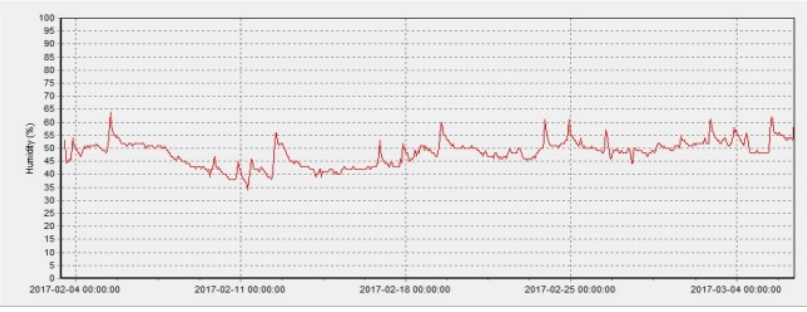

b)

Fig. 10. a) Graphical variation of temperature $\left({ }^{0} \mathrm{C}\right)$;

b) Graphical variation of relative humidity (\%).

It can be observed from the fig.10 that the temperature in church has a mean value for the winter season, particularly for the time when the measurement were taken of $\mathrm{T} \approx 15^{\circ} \mathrm{C}$. The humidity has value between $\mathrm{rH}=35 \%-65 \%$. 
To give a better understanding of the microclimate, there was made a statistical interpretation of the measured parameters of thermal comfort. The statistical analysis refers to show the standard deviation and the trusted values been exemplify trough histograms and boxplots.

The microclimate from Cetăția Monastery church shows (fig. 11,12) that the temperature are in a large scale between $12-20{ }^{0} \mathrm{C}$, with a mean value of temperature around $15,45{ }^{\circ} \mathrm{C}$, with a standard deviation of 1,575 , given by the histogram plot in figure 11,12 .

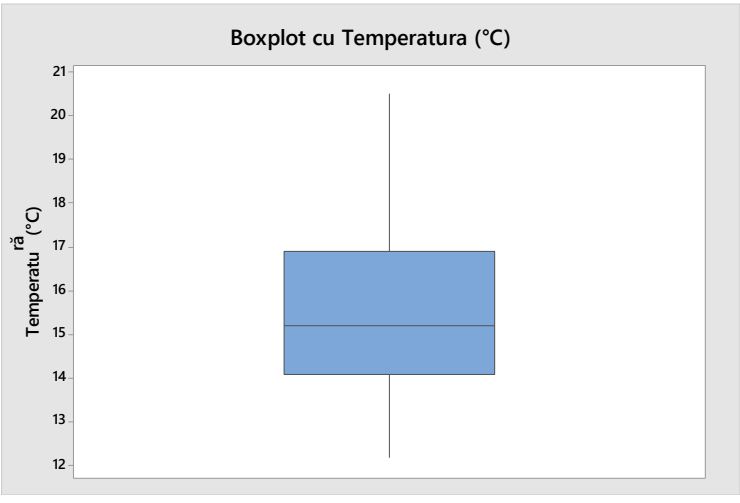

Fig. 11. Temperature boxplot in Cetățuia Monastery Church.

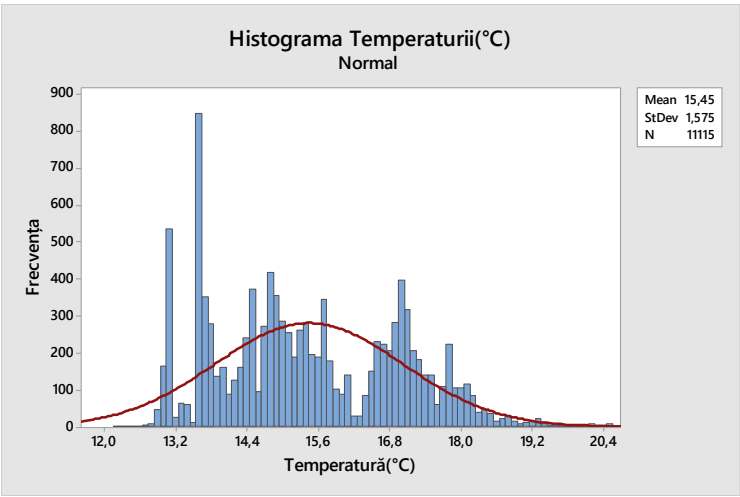

Fig. 12. Temperature histogram in Cetățuia Monastery Church.

Also it can be seen a variation of humidity with peak loads in a quick time. The mean value of humidity is around $48,20 \% \mathrm{rH}$ in a scale between minimum of $35 \%$ and maximum of $64 \%$, with a standard deviation of 4,745 (Fig. 13, Fig.14).

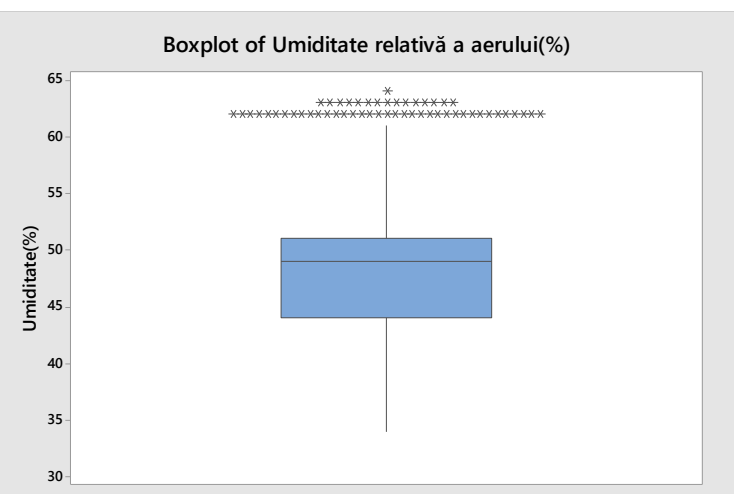

Fig. 13. Relative humidity of air boxplot in St. Sava Church.

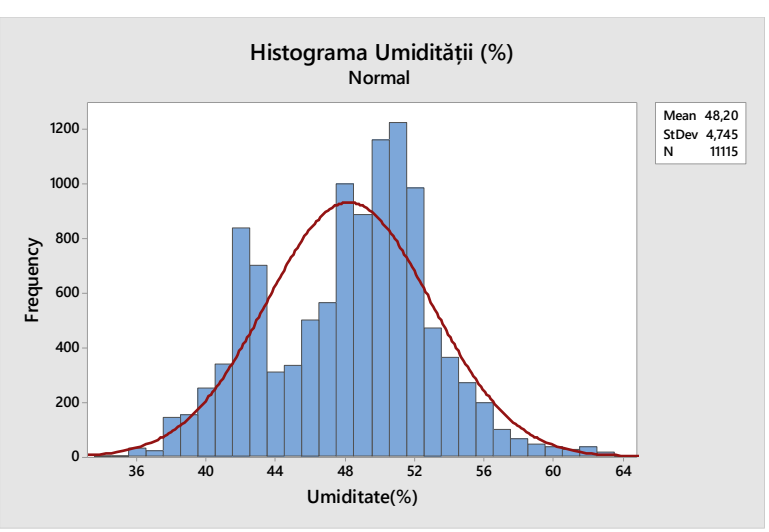

Fig. 14. Relative Humidity of air histogram in St. Sava Church.

The indoor climate condition described in figure 10 to 14 relief that there is maintaining a minim level of comfort, the maximum values of temperature and humidity are recorded during the liturgical service when people gather are in high number. Very quick variation of this parameters in a short period of time can have a bad influence over the frescos and wooden objects in the church. [7]

There were calculated the comfort index PMV and PPV for the indoor microclimate based on the activity and data taken from the measurement (Fig.15).

\begin{tabular}{|l|c|}
\hline Parame ters for the rmal comfort & Dates \\
\hline Thermal insulation of clothes (clo) & 1,00 \\
\hline Air Termperature $\left({ }^{\circ} \mathrm{C}\right)$ & 15,6 \\
\hline Mean radiant temperature $\left({ }^{\circ} \mathrm{C}\right)$ & 16,5 \\
\hline Metabolic rate $($ met) & 1,2 \\
\hline Air speed $(\mathrm{m} / \mathrm{s})$ & 0,06 \\
\hline Relative humidity of air $(\%)$ & 48,2 \\
\hline \multicolumn{2}{|c|}{$\mathrm{PMV}-\mathrm{PPD}$} \\
\hline Index of thermal comfort & Rezults \\
\hline Perceived temperature $\left({ }^{\circ} \mathrm{C}\right)$ & $\mathbf{1 6 , 0 5}$ \\
\hline PMV & $\mathbf{- 1 , 2}$ \\
\hline PPD & $\mathbf{3 5 , 2}$ \\
\hline
\end{tabular}

Fig. 15. Parameters need to evaluate the level of comfort based on the comfort index PMV and PPD in Cetăția Monastery Church.

The comfort graph is show in the figure 16 .

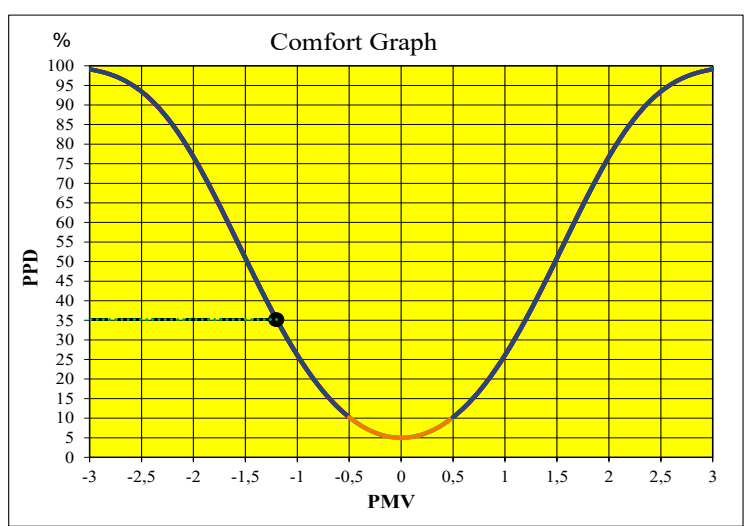

Fig. 16. Comfort graph of PMV and PPD index in Cetățuia Monastery Church. 
From the Figure 15 and 16 it can be observed that the level of comfort is medium to high with a degree of satisfaction, approximately of $65 \%$, this showing that the heating system is assuring a comfortable environment for the churchgoers.

\section{Microclimate modelling}

Within the research, the CFD package of Autodesk CFD, version 2019 was used. Software used is Autodesk 2019 - capable of solving heat, air and water vapour simulation, the analysis was run in steady state. The $3 \mathrm{~d}$ model was made in Autodesk Inventor 2019 (Fig. 17), in order to have a model at real scale closed to the investigation site.

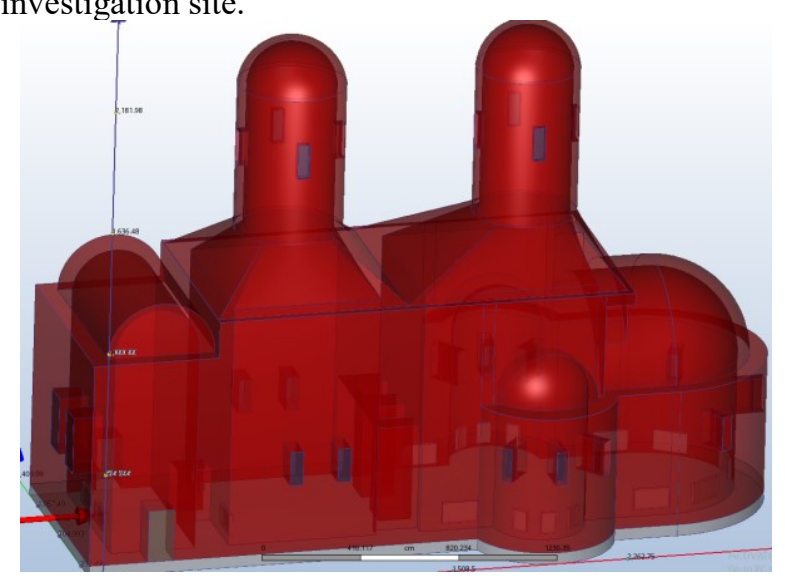

Fig. 17. Cetățuia Monastery Church $3 d$ modelling.

The model was build using Cartesian coordinates, in which a non-structural grid was applied. The idea behind the non-structural grid was to properly model the indoor climate. Within the CFD model, the equation for Flow, Turbulence, and Energy were solved. The discretization schemes for these equations are: Standard, Simple and the First Order scheme for Momentum, Turbulence Kinetic Energy, Turbulence Dissipation rate and Energy (Fig. 18).

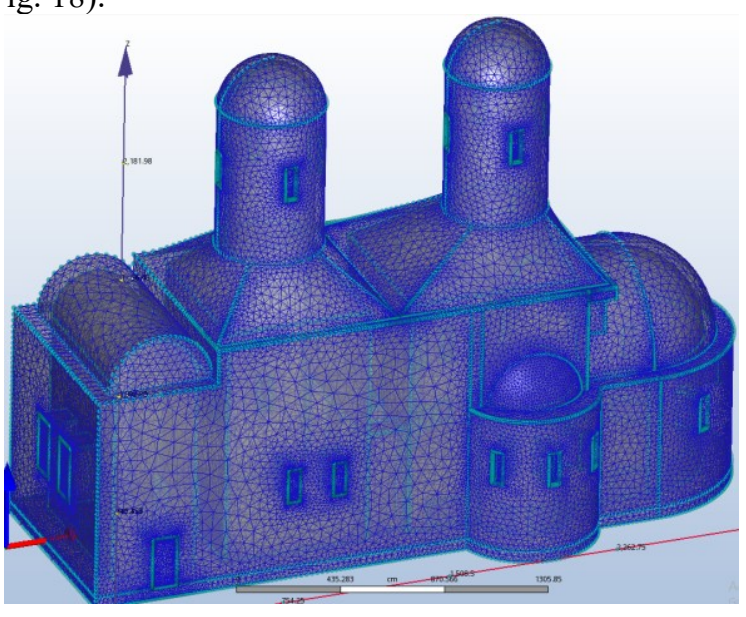

Fig. 18. Mesh discretization of the Cetățuia Monastery Church at $8.6 \mathrm{M}$ elements.

The boundary conditions imposed for the analysis for the walls, ceiling and floor as for the heating system is presented in the table 1 .
The standard k-epsilon model with standard wall function were used to perform CFD simulation and the mesh size was increased to check if the results get more accurate. The meshing discretization was made in Autodesk CFD Simulation software. Without adjusting the size based on local curvature and having both fluid and solid zones we have a first mesh of $4.6 \mathrm{M}$ elements, both for static and underfloor heating systems simulations.

For the next three simulation we increased the refinement resulting a number of $8.6 \mathrm{M}$ elements (Fig. 18).

Table 1. Boundary conditions.

\begin{tabular}{|c|c|c|}
\hline Boundary condition & Symbol & Value \\
\hline $\begin{array}{c}\text { Heat flux for static } \\
\text { heaters }\end{array}$ & $\mathrm{Q}_{\mathrm{s}}$ & $280 \mathrm{~W} / \mathrm{m}^{2}$ \\
\hline $\begin{array}{c}\text { Heat flux for } \\
\text { underfloor heating } \\
\text { system }\end{array}$ & $\mathrm{Q}_{\mathrm{u}}$ & $120 \mathrm{~W} / \mathrm{m}^{2}$ \\
\hline $\begin{array}{c}\text { Temperature for } \\
\text { exterior walls, } \\
\text { windows, roof door }\end{array}$ & $\mathrm{T}_{\mathrm{e}}$ & $-16^{\circ} \mathrm{C}$ \\
\hline $\begin{array}{c}\text { Temperature for floor } \\
\text { on the ground }\end{array}$ & $\mathrm{T}_{\mathrm{S}}$ & $10^{\circ} \mathrm{C}$ \\
\hline $\begin{array}{c}\text { Film coefficient for } \\
\text { walls }\end{array}$ & $\mathrm{U}_{\mathrm{w}}$ & $0.492 \mathrm{~W} / \mathrm{m}^{2} \mathrm{~K}$ \\
\hline $\begin{array}{c}\text { Film coefficient for } \\
\text { floor on the ground }\end{array}$ & $\mathrm{U}_{\mathrm{g}}$ & $0.31 \mathrm{~W} / \mathrm{m}^{2} \mathrm{~K}$ \\
\hline
\end{tabular}

Because the heat was not introduced by forced ventilation, but by natural convection from the heating elements, both for static and underfloor heating system, the Boussinesq approximation was used for the air density.

\subsection{Results}

The comparison of the CFD results with the experimental data is done both by qualitatively and quantitatively through section plans from the church and graph of temperature and air velocity variation in the area where the sensor was placed in the church.

In Fig. 19 it can be seen that the temperature have a stratifying distribution and that in the influence zone of the heaters the air has higher speed.

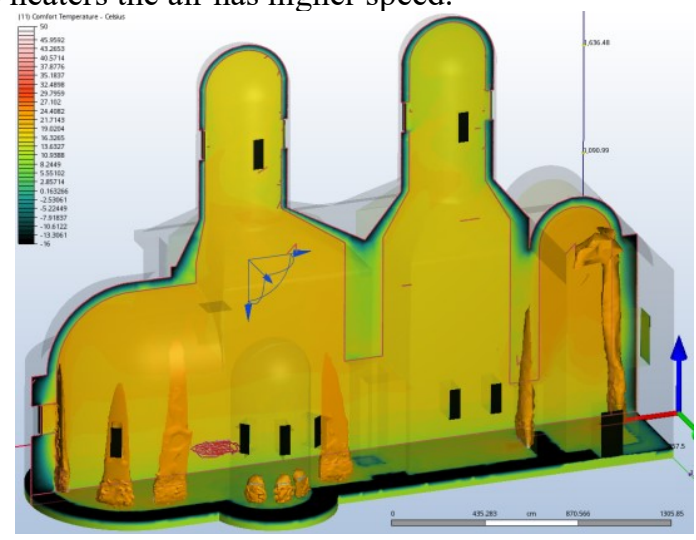

Fig. 19. Temperature in the section plans of Cetățuia Monastery Church. 
From the Fig. 20, in the cross section plans of the church it can be seen that the air velocity has higher speed, mainly due to the underfloor heating system compare with the cross section from figure 21 , where the heating system is only with static heaters that creates air current in the influence zone, especially on the support wall.

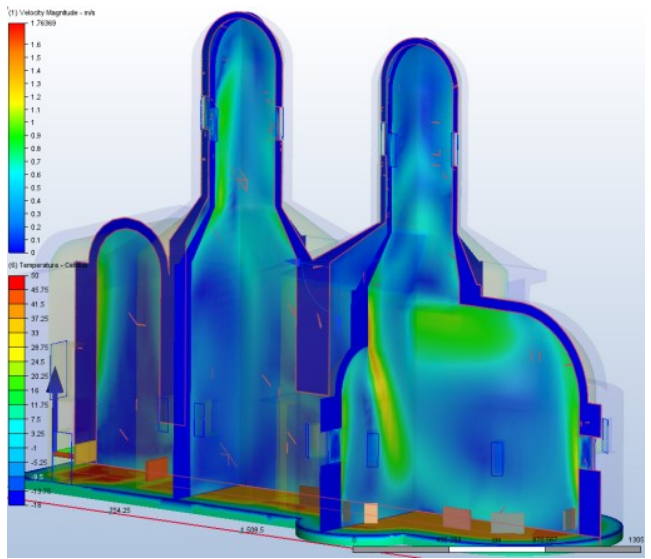

Fig. 20. Air speed velocity in the section plans taken in Cetăţuia Monastery Church due to underfloor heating system.

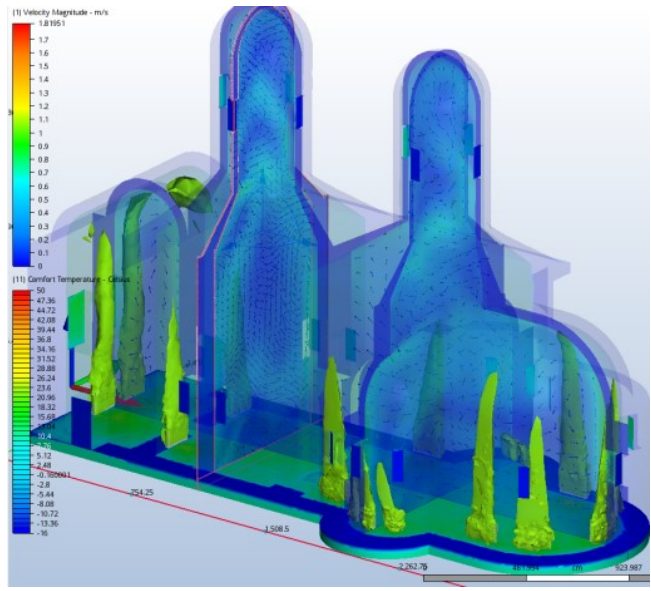

Fig. 21. Air speed velocity in the section plans taken in Cetățuia Monastery Church due to static heaters.

The variation of the temperature is represented in Fig. 22, with a mean temperature of approximatively $17.5{ }^{\circ} \mathrm{C}$, which is appropriate to the temperature from the underfloor heating system Fig. 23 of $17.80^{\circ} \mathrm{C}$.

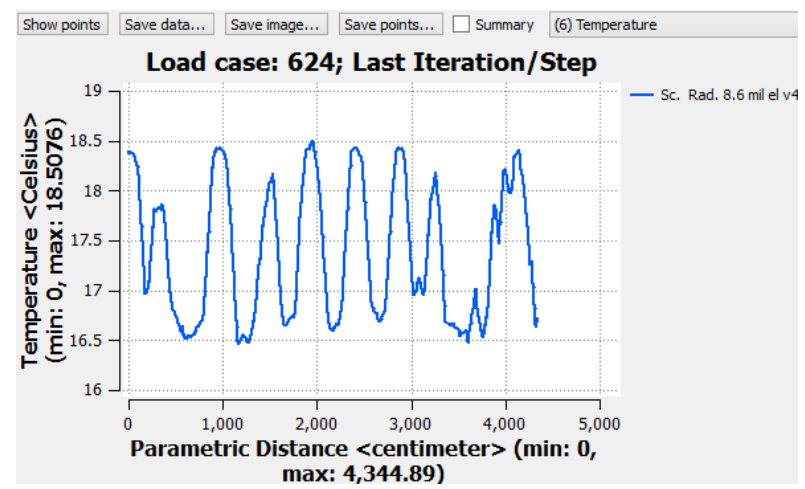

Fig. 22. Temperature graph in Cetățuia Monastery Church generated by static heaters.

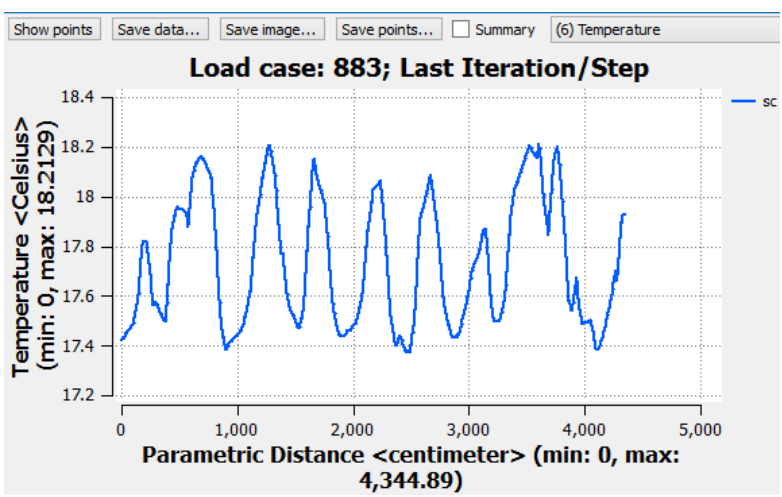

Fig. 23. Temperature graph in Cetățiia Monastery Church generated by underfloor heating system.

\section{Conclusion and further developments}

From the viewpoint of thermal comfort, more research has to be performed in order to rate the human thermal comfort in the church heated with static heaters and underfloor heating system.

The situation proposed for heating the church (using underfloor heating system) is very complex in which people are wearing thick winter cloths. In this case study the underfloor heating system seems to be a nice alternative for the "old" static heaters heating system that heats the whole air volume of the church.

\section{References}

[1] Fumo, N., A review on the basics of building energy estimation. RENEW SUST ENERG REV, 31, pp. 53-60, (2014);

[2] Khalil, E. E., Air distribution in buildings. 1st ed. Broken Sound Parkway, New York: Taylor \& Francis, (2014);

[3] Popovici, C. G., Hudişteanu, V. H., Cherecheş, N. C., The necessity of HVAC system for the registered architectural cultural heritage building, E3S Web of Conferences, 32, p8. 01-08, (2018);

[4] Kim, D., Braun, J., Cliff, E. \& Borggaard. , J.,. Development, Validation and Application of a Coupled ReducedOrder CFD Model for Building Control Applications. Build Environ, 93, pp. 97-111, (2015);

[5] Royapoor , M. \& Roskilly, . T., Building model calibration using energy and environmental data. Energy and Buildings, 94, pp. 109-120, (2015);

[6] Burlacu, A., Ciocan, V., Verdes, M., Popovici, G.C., Balan, M.C., Tofan, B.A., Pastrav, D., Experimental study for data validation regarding the flow movement in natural convection in an asymmetrical heated vertical channel, AMM, Vol. 659 (2014) pp. 313-318;

[7] Varas-Muriel, M. et al., Fluctuations in the indoor environment in Spanish rural churches and their effects on heritage conservation: Hygro-thermal and $\mathrm{CO} 2$ conditions monitoring. Build Enviro, 82, pp. 97-109, (2014). 